\title{
Opinion: Why Should We Care about Endocrine Disruptors?
}

\author{
Lyuba Varticovski*, Diana A. Stavreva and Gordon L. Hager* \\ Laboratory or Receptor Biology and Gene Expression, NCI, NIH, 41 Library Road, NIH, Bethesda, MD USA \\ ${ }^{\star}$ Corresponding author: Dr. Gordon L. Hager, Laboratory or Receptor Biology and Gene Expression, NCI, NIH, 41 Library Road, NIH, Bethesda, MD USA; Email: \\ hagerg@dce41.nci.nih.gov
}

Received: December 18, 2021; Accepted: December 23, 2021; Published: January 05, 2022

The Endocrine Disruptors (EDCs) are defined as "exogenous chemical, or mixture of chemicals, that interfere with any aspect of hormone action", and in 2015, the Endocrine Society convened a large group of experts to review in-depth the state of science on EDCs [1]. Over the years a massive accumulation of data supports growing concern on EDCs' harmful effects on humans and all other living organisms.

\section{A. Why Do We Care so much about EDCs?}

1. We care because EDCs interfere with the normal function of the endocrine system and can harm every organ of a living organism.

2. EDCs are especially dangerous for the developing fetus and their effects can persist to affect early life, adulthood, and even follow to the next generations.

3. EDCs are present in food, water, air, soil, cosmetics, medicines, toys, and other items. They accumulate in living organisms and the aquatic species are particularly vulnerable.

\section{B. What Do We Need to Know for Efficient Detection and Monitoring of EDCs?}

1. The status on the methods of detection

\section{Why Do We Need Public Awareness of EDCs Effects?}

Because their presence in the environment is not well sufficiently regulated, and the screening methods do not always include a biological read-out. An excellent example is Bisphenol A (BPA) which was synthesized in 1936 as an estrogenic compound. Subsequently it was discovered that BPA activates other nuclear receptors, including thyroid receptor (TR). Despite recent restrictions, BPA is one of the highest production-volume chemicals used in manufacturing polycarbonate plastics and epoxy resins.

1. Several major manufacturers of baby bottles removed BPA from their products after a public outcry.

2. Unfortunately, all of us have BPA in our bodies because it is in food, household, and industrial items, including linings of canned foods and drinks.

\section{Why are We Still Deliberating about Harmful Effects of EDCs?}

1. The major reasons are that we lack uniform agreement among scientific community on "safe" levels of EDCs. Some consider that any exposure is unacceptable, while others call for establishing a low dose limit for specific products.

2. Regulatory agencies world-wide have not provided sufficient restrain for continuing accumulation of EDCs in the environment.

3. Industry and environmental non-government organizations present conflicting information, and the lay press oversimplifies the research results, leading to a confusing state of information for many EDCs.

\section{A. Why Do We Care so much about EDCs?}

The endocrine system evolved to respond to very low levels of hormones [2-4]. Because of common receptor-mediated mechanisms, EDCs that mimic natural hormones are likely to have biological effects in humans and other species [4-6]. Moreover, small changes in hormonal concentrations can have biologically important consequences [2,4]. Thus, EDCs can have adverse effects on living organisms, and even low doses of contaminants cannot be ignored.

Many EDCs exert their effects as agonists or antagonists by direct interaction with hormonal receptors: estrogen (ERs), progesterone (PR), androgen (ARs), thyroid hormone (TRs), and with nuclear receptors that regulate metabolism and differentiation, such as aryl hydrocarbon (AhR), retinoid X (RXR), peroxisome proliferatoractivated (PPARs), liver X (LXRs), and farsenoid X receptors (FXRs) [7]. Following ligand binding, the receptors become transcription factors that regulate expression of many genes.

The most sensitive time for exposure to EDCs is during fetal development [8]. Some EDCs affect fetal development in late pregnancy [9] whereas others are harmful even before the woman is aware of her pregnancy $[10,11]$. EDCs can also lead to harmful traits carried over to future generations (transgenerational effects) [12], although they do not induce changes in DNA sequence [13]. Thus, the harmful effects may not be immediately apparent, which makes it difficult to discern from other causes.

Long-lasting effects on male and female fertility in several species are particularly of concern $[14,15]$ and the decline in male and female fertility has been detected world-wide [16]. Detection of EDCs in blood, urine, milk, and tissues showed alarming results reflecting global exposure [10]. 
EDCs can harm every organ in the body. Let's start with the brain. EDCs can change the expression, abundance, and distribution of steroid hormones and other nuclear receptors in the developing brain. There are multiple documented functional consequences of altered receptor action in fish brain and the most widely studied compounds are BPA and polychlorinated biphenyls (PCBs) $[17,18]$. All living organisms that consume untreated water are exposed because water is frequently contaminated by pollutants originating from municipal and industrial wastewater effluents, as well as runoffs from livestock and agricultural areas.

In addition to harmful effects on the brain, perinatal exposure to low doses of BPA causes metabolic derangements: increased body weight; adiposity; alterations in blood levels of insulin, leptin, and adiponectin; as well as a decrease in glucose tolerance and insulin sensitivity in an age-dependent manner [19-21].

One of most studied group of EDCs are estrogenic compounds which regulate estrogen receptor (ER) with broad effects on bone mineralization, immunity, male and female reproduction, metabolism, and many other biological processes. The presence of estrogenic substances in the environment has been known for over a century and increased significantly across the globe in the last 50 years. Clover species were documented to contain high amounts of estrogen receptor-activating compounds leading to reproductive disorders in cows and sheep fed with clover-rich diet [22]. Because hormonal synthesis and their world-wide use exploded during the 1940's, toxicologists noticed their presence in the environment and described the effects on organisms. In US, studies in 1965 [23], in 1970 [24] and thereafter increased public concern for estrogenic chemicals. Although in 1990 the United States Congress updated the US Safe Drinking Water Act to include screening programs to detect estrogenic contaminants, harmful effects of estrogens [25,26] and progestogens, specifically on fish reproduction, have been increasingly documented $[27,28]$.

Thyroid hormone (TH) disruptors are also of particular concern because they govern neurodevelopment and metabolic homeostasis. Exposure during pregnancy has been linked to the rise in autism and cognitive disorders [29-32], as well as increased risk to develop thyroid cancer [33]. Because TH cooperates with progesterone during implantation, TH disruptors also impair pregnancy [34]. Thyroid receptor interacting compounds are widely spread in the US rivers $[35,36]$. The agonists and antagonists are especially prevalent in water downstream of intense urbanization and livestock production. Triiodothyronine (T3)-like activity are reported in effluents from water treatment plants (WWTP) in Japan [37], and anti-T3 hormonal activity was found in WWTP effluent in Thailand [38].

Weakened immune systems with increased susceptibility to infections are likely due to exposures to glucocorticoids alone or in combination with other EDCs, have been associated with fish kills [39-42].

These are only a few examples of well-documented studies on harmful effects of EDCs.

\section{B. What Do We Need to Know for Efficient Detection and Monitoring of EDCs?}

Because of the growing concern on contamination of the environment $[1,37,38,43-46]$, significant attention and investment has been devoted to their detection [47]. Laborious chemical methods of isolation and identifications by a combination of HPLC, liquid or gas chromatography and/or mass spectroscopy, were followed by "omic" approaches (genomics, transcriptomics, proteomics, and/ or metabolomics) in fish and other affected organisms $[48,49]$. Unfortunately, these assays are laborious, costly and identify only a single compound. In addition, lack of uniform quantification and uncertainty of their biological effects limit their use. Thus, analytical strategies based on target chemical analyses have been insufficient to depict meaningful environmental contamination.

Technical innovations using luciferase reporters or fluorescent tags in genetically engineered yeast, mammalian cell lines, or whole organisms, such as zebra fish, led to development of assays in which the read-out is a biological effect elicited by a specific receptor $[35,36,50$ 53]. Many of these methods are sensitive in the below nanomolar range, amenable to high throughput and do not require identification of ligand's chemical structure.

\section{Why Do We Need Public Awareness of EDCs Effects?}

Extensive documentation on the adverse effects of exposure to BPA on reproduction and development, cardiovascular, neurological, metabolic, and immune systems [54,55], led to reduction of reference dose by European Food Safety Authority, stronger restrictions and regulations on the production and usage of BPA in North America in 1990, European Union and in Canada in 2010 [56]. It was estimated that $93 \%$ of Americans have measurable amounts of BPA in urine $[57,58]$ and because of the wide-spread contamination with BPA, these levels are likely to persist. After substantial public pressure, in 2008 six major manufacturers of baby bottles removed BPA from their products and the trend continues in developing BPA-free goods and materials.

However, many recently developed BPA analogues have also been detected in the environment. Some have similar estrogenic, antiandrogenic and TH disrupting activities [59]. Thus, sustained public awareness and negative publicity is needed to remove BPA and its analogs to prevent further environmental contamination and human exposure.

\section{Why are We Still Deliberating about Harmful Effects of EDCs?}

Lack of consensus in the scientific community on quantitative methods for detection and "safe" levels of sex hormones in the environment and other EDCs is a major obstacle for development of a rational policy for efficient monitoring and establishing safety limits to protect wildlife and human health. Scientific evidence indicates complex mechanisms operating at low doses showing nonmonotonic dose-response curves (2). A largely unexplored issue is the combined effect of a mixture of EDCs detected in the same sample. Many water sites have several EDCs that interact with glucocorticoid, estrogen, 
progesterone, thyroid, aryl hydrocarbon and other nuclear receptors [35,52,60-63]. The combinations further modify the biological outcomes as these mixtures are likely to have unexplored effects on target tissues [4,64]. Interactions with receptors, nuclear cofactors, and chromatin remodelers through "assisted loading" mechanisms further modify gene expression $[47,65,66]$. Some of these epigenetic changes may be long-lasting and possibly inheritable.

As presented in this Opinion, scientific evidence linking EDCs to health effects is strong, but regulations have not kept up with the endocrine science. Despite EPA regulation in US, and WHO efforts in periodic updates (most recently in 2012) the state of science on contamination of water, air and soil, EDCs threaten the integrity of the planet's ecosystems and pose serious concerns for human and animal health $[1,46]$.

The potential to link epidemiological studies with individual exposure assessments is now feasible. Current eHealth programs, such as All-of-Us, can be critical in evaluating pathophysiology and establishing the temporal relationship between markers of exposure and long-term effects. This is the time for high-level meetings to bring together all critical players with the twin goal of sharing information and considering options for investment in global EDCs detection and monitoring. Only then we can advise on regulatory policies with particular emphasis in relation to human disease. Virtual platforms, popular since 2020 during the COVID-19 pandemic, can make such efforts possible. Scientific knowledge gives national and international agencies an informed opinion on controlling specific aspects of environmental contaminants. A coordinated program encompassing governmental and public organizations and industry leaders with scientists would enable a science-based approach to better understand and halt the impact of EDCs pollution on ecosystems and human health.

\section{References}

1. Gore AC, Chappell VA, Fenton SE, Flaws JA, Nadal A, et al. (2015) EDC-2: The Endocrine Society's Second Scientific Statement on Endocrine-Disrupting Chemicals. Endocr Rev 36: E1-E150. [crossref]

2. Vandenberg LN, Colborn T, Hayes TB, Heindel JJ, Jacobs DR, et al. (2012) Hormones and endocrine-disrupting chemicals: low-dose effects and nonmonotonic dose responses. Endocr Rev 33: 378-455.

3. Eick GN, Thornton JW (2011) Evolution of steroid receptors from an estrogensensitive ancestral receptor. Mol Cell Endocrinol 334: 31-38. [crossref]

4. Welshons WV, Thayer KA, Judy BM, Taylor JA, Curran EM, et al. (2003) Large effects from small exposures. I. Mechanisms for endocrine-disrupting chemicals with estrogenic activity. Environ Health Perspect 111: 994-1006. [crossref]

5. Hayes TB, Anderson LL, Beasley VR, Solla SRD, Iguchi T, et al. (2011) Demasculinization and feminization of male gonads by atrazine: consistent effects across vertebrate classes. J Steroid Biochem Mol Biol 127: 64-73. [crossref]

6. Sheehan DM (2000) Activity of environmentally relevant low doses of endocrine disruptors and the bisphenol A controversy: initial results confirmed. Proc Soc Exp Biol Med 224: 57-60. [crossref]

7. Swedenborg E, Ruegg J, Makela S, Pongratz I (2009) Endocrine disruptive chemicals: mechanisms of action and involvement in metabolic disorders. J Mol Endocrinol 43: 1-10. [crossref]

8. Philippat C, Nakiwala D, Calafat AM, Botton J, Agostini MD, et al. (2017) Prenatal Exposure to Nonpersistent Endocrine Disruptors and Behavior in Boys at 3 and 5 Years. Environ Health Perspect 125: 097014. [crossref]
9. Ohtani N, Suda K, Tsuji E, Tanemura K, Yokota H, et al. (2018) Late pregnancy is vulnerable period for exposure to BPA. J Vet Med Sci 80: 536-543. [crossref]

10. Fucic A, Galea KS, Duca RC, Yamani ME, Frery N, et al. (2018) Potential Health Risk of Endocrine Disruptors in Construction Sector and Plastics Industry: A New Paradigm in Occupational Health. Int J Environ Res Public Health 15: 1229. [crossref]

11. Grindler NM, Vanderlinden L, Karthikraj R, Kannan K, Teal S, et al. (2018) Exposure to Phthalate, an Endocrine Disrupting Chemical, Alters the First Trimester Placental Methylome and Transcriptome in Women. Sci Rep 8: 6086.

12. Brehm E, Flaws JA (2019) Transgenerational Effects of Endocrine-Disrupting Chemicals on Male and Female Reproduction. Endocrinology 160: 1421-1435. [crossref]

13. Ankolkar M, Balasinor NH (2016) Endocrine control of epigenetic mechanisms in male reproduction. Horm Mol Biol Clin Investig 25: 65-70.

14. Rattan, S. Zhou C, Chiang C, Mahalingam S, Brehm E, et al. (2017) Exposure to endocrine disruptors during adulthood: consequences for female fertility. J Endocrinol 233: R109-R129. [crossref]

15. Zoeller RT, Bergman A, Becher G, Bjerregaard P, Bornman R, et al. (2014) A path forward in the debate over health impacts of endocrine disrupting chemicals. Environ Health 13: 118.

16. Vander Borght M, Wyns C (2018) Fertility and infertility: Definition and epidemiology. Clin Biochem 62: 2-10. [crossref]

17. Page YL, Vosges M, Servili A, Brion F, Kah O (2011) Neuroendocrine effects of endocrine disruptors in teleost fish. J Toxicol Environ Health B Crit Rev 14: 370-386. [crossref]

18. Segner H, Ayako CN, Kase R, Tyler CR (2013) Impact of environmental estrogens on Yfish considering the diversity of estrogen signaling. Gen Comp Endocrinol 191: 190-201. [crossref]

19. Long Z, Fan J, Wu G, Liu X, Wu H, et al. (2021) Gestational bisphenol A exposure induces fatty liver development in male offspring mice through the inhibition of HNF1b and upregulation of PPARgamma. Cell Biol Toxicol 37: 65-84. [crossref]

20. MacKay H, Patterson ZR, Abizaid A (2017) Perinatal Exposure to Low-Dose Bisphenol-A Disrupts the Structural and Functional Development of the Hypothalamic Feeding Circuitry. Endocrinology 158: 768-777. [crossref]

21. Rubin BS, Soto AM (2009) Bisphenol A: Perinatal exposure and body weight. Mol Cell Endocrinol 304: 55-62. [crossref]

22. Adams AL, Harris B Jr, Van Horn HH, Wilcox CJ (1995) Effects of varying forage types on milk production responses to whole cottonseed, tallow, and yeast. J Dairy Sci 78: 573-581. [crossref]

23. Stumm-Zollinger E, Fair GM (1965) Biodegradation of steroid hormones. J Water Pollut Control Fed 37: 1506-1510.

24. Tabak HH, Bunch RL (1970) Steroid hormones as water pollutants. Metabolism of natural and synthetic ovulation-inhibiting hormones by microorganisms of activated sludge and primary settled sewage. Developments in Industrial Microbiology 11: 367376 .

25. Alvarez DA, Cranor WL, Perkins SD, Schroeder VL, Iwanowicz LR, et al. (2009) Reproductive health of bass in the Potomac, U.S.A. drainage: part 2. Seasonal occurrence of persistent and emerging organic contaminants. Environ Toxicol Chem 28: 1084-1095. [crossref]

26. Blazer VS, Pinkney AE, Jenkins JA, Iwanowicz LR, Minkkinen S, et al. (2013) Reproductive health of yellow perch Perca flavescens in selected tributaries of the Chesapeake Bay. Sci Total Environ 447: 198-209. [crossref]

27. Paulos P, Runnalls TJ, Nallani G, La Point T, Scott AP, et al. (2010) Reproductive responses in fathead minnow and Japanese medaka following exposure to a synthetic progestin, Norethindrone. Aquat Toxicol 99: 256-262. [crossref]

28. Zeilinger J, Steger-Hartmann T, Maser E, Goller S, Vonk R, et al. (2009) Effects of synthetic gestagens on fish reproduction. Environ Toxicol Chem 28: 2663-2670. [crossref]

29. Ghassabian A, Trasande L (2018) Disruption in Thyroid Signaling Pathway: A Mechanism for the Effect of Endocrine-Disrupting Chemicals on Child Neurodevelopment. Front Endocrinol (Lausanne) 9: 204. [crossref] 
30. Levie D, Korevaar TIM, Bath SC, Dalmau-Bueno A, Murcia M, et al. (2018) Thyroid Function in Early Pregnancy, Child IQ, and Autistic Traits: A Meta-Analysis of Individual Participant Data. J Clin Endocrinol Metab 103: 2967-2979. [crossref]

31. Ozzola G (2016) Pollution, the thyroid and neurodevelopment. Clin Ter 167: 191-197. [crossref]

32. Salazar P, Villaseca P, Cisternas P, Inestrosa NC (2021) Neurodevelopmental impact of the offspring by thyroid hormone system-disrupting environmental chemicals during pregnancy. Environ Res 200: 111345. [crossref]

33. Alsen M, Sinclair C, Cooke P, Ziadkhanpour K, Genden E, et al. (2021) Endocrine Disrupting Chemicals and Thyroid Cancer: An Overview. Toxics 9: 14. [crossref]

34. Kakita-Kobayashi M, Murata H, Nishigaki A, Hashimoto Y, Komiya S, et al. (2020) Thyroid Hormone Facilitates in vitro Decidualization of Human Endometrial Stromal Cells via Thyroid Hormone Receptors. Endocrinology 161: 40. [crossref]

35. Stavreva DA, Collins M, McGowan A, Varticovski L, Raziuddin R, et al. (2021) Mapping multiple endocrine disrupting activities in Virginia rivers using effectbased assays. Sci Total Environ 773: 145602. [crossref]

36. Stavreva DA, Varticovski L, Levkova L, George AA, Davis L, et al. (2016) Novel cell-based assay for detection of thyroid receptor beta-interacting environmental contaminants. Toxicology 368-369: 69-79. [crossref]

37. Murata T, Yamauchi K (2008) 3,3,5-Triiodo-L-thyronine-like activity in effluents from domestic sewage treatment plants detected by in vitro and in vivo bioassays. Toxicol Appl Pharmacol 226: 309-317. [crossref]

38. Ishihara A, Rahman FB, Leelawatwattana L, Prapunpoj P, Yamauchi K (2009) In vitro thyroid hormone-disrupting activity in effluents and surface waters in Thailand. Environ Toxicol Chem 28: 586-594. [crossref]

39. Ankley GT, Jensen KM, Makynen EA, Kahl MD, Korte JJ, et al. (2003) Effects of the androgenic growth promoter 17-beta-trenbolone on fecundity and reproductive endocrinology of the fathead minnow. Environ Toxicol Chem 22: 1350-1360. [crossref]

40. Blazer VS, Iwanowicz LR, Starliper CE, Iwanowicz DD, Barbash P, et al. (2010) Mortality of centrarchid fishes in the Potomac drainage: survey results and overview of potential contributing factors. J Aquat Anim Health 22: 190-218. [crossref]

41. Ripley J, Iwanowicz L, Blazer V, Foran C (2008) Utilization of protein expression profiles as indicators of environmental impairment of smallmouth bass (Micropterus dolomieu) from the Shenandoah River, Virginia, USA. Environ Toxicol Chem 27: 1756-1767. [crossref]

42. Zhang J, Yang Y, Liu W, Schlenk D, Liu J (2019) Glucocorticoid and mineralocorticoid receptors and corticosteroid homeostasis are potential targets for endocrinedisrupting chemicals. Environ Int 133: 105133. [crossref]

43. Diamanti-Kandarakis E, Bourguignon JP, Giudice LC, Hauser R, Prins GS, et al. (2009) Endocrine-disrupting chemicals: an Endocrine Society scientific statement. Endocr Rev 30: 293-342.

44. Kusk KO, Kruger T, Long M, Taxvig C, Lykkesfeldt AE, et al. (2011) Endocrine potency of wastewater: contents of endocrine disrupting chemicals and effects measured by in vivo and in vitro assays. Environ Toxicol Chem 30: 413-426. [crossref]

45. Van der Linden SC, Heringa MB, Man HY, Sonneveld E, Puijker LM, et al. (2008) Detection of multiple hormonal activities in wastewater effluents and surface water, using a panel of steroid receptor CALUX bioassays. Environ Sci Technol 42: 58145820. [crossref]

46. Bergman Åea (2013) State of the science of endocrine disrupting chemicals 2012: summary for decision-makers. World Health Organization, WHO/HSE/PHE/ IHE/2013.1, 180

47. Varticovski L, Stavreva DA, McGowan A, Raziuddin R, Hager GL (2022) Endocrine disruptors of sex hormone activities. Mol Cell Endocrinol 539: 111415. [crossref]

48. Jordan KW, Adkins CB, Cheng LL, Faquin WC (2011) Application of magneticresonance-spectroscopy- based metabolomics to the fine-needle aspiration diagnosis of papillary thyroid carcinoma. Acta Cytol 55: 584-589.
49. Mansilha C, Melo A, Rebelo H, Ferreira IM, Pinho O, et al. (2010) Quantification of endocrine disruptors and pesticides in water by gas chromatography-tandem mass spectrometry. Method validation using weighted linear regression schemes. Chromatogr A 1217: 6681-6691.

50. Escher BI, Allinson M, Altenburger R, Bain PA, Alaguer P, et al. (2014) Benchmarking organic micropollutants in wastewater, recycled water and drinking water with in vitro bioassays. Environ Sci Technol 48: 1940-1956. [crossref]

51. Zhao Y, Zhang K, Fent K (2016) Corticosteroid Fludrocortisone Acetate Targets Multiple End Points in Zebrafish (Danio rerio) at Low Concentrations. Environ Sc Technol 50: 10245-10254. [crossref]

52. Stavreva DA, George AA, Klausmeyer P, Varticovski L, Sack D, et al. (2012) Prevalent glucocorticoid and androgen activity in US water sources. Sci Rep 2: 937.

53. Brack W, Klamer HJC, Alda MLD, Barcelo D (2007) Effect-directed analysis of key toxicants in European river basins a review. Environ Sci Pollut Res Int 14: 30-38. [crossref]

54. Vandenberg LN, Hauser R, Marcus M, Olea N, Wlshons WV (2007) Human exposure to bisphenol A (BPA). Reprod Toxicol 24: 139-177. [crossref]

55. vom Saal FS, Akingbemi BT, Belcher SM, Birnbaum LS, Crain DA, et al. (2007) Chape Hill bisphenol A expert panel consensus statement: integration of mechanisms, effects in animals and potential to impact human health at current levels of exposure. Reprod Toxicol 24: 131-138. [crossref]

56. Resnik DB, Elliott KC, Bisphenol A (2015) and risk management ethics. Bioethics 29: 182-189. [crossref]

57. Calafat AM, Ye X, Wong LY, Reidy JA, Needham LL (2008) Exposure of the U.S population to bisphenol A and 4-tertiary-octylphenol: 2003-2004. Environ Health Perspect 116: 39-44. [crossref]

58. Dekant W, Volkel W (2008) Human exposure to bisphenol A by biomonitoring: methods, results and assessment of environmental exposures. Toxicol Appl Pharmacol 228: 114-134. [crossref]

59. Chen D, Kannan K, Tan H, Zheng Z, Feng YL, et al. (2016) Bisphenol Analogues Other Than BPA: Environmental Occurrence, Human Exposure, and Toxicity-A Review. Environ Sci Technol 50: 5438-5453. [crossref]

60. Jones RR, Stavreva DA, Weyer PJ, Varticovski L, Inoue-choj M, et al. (2020) Pilot study of global endocrine disrupting activity in Iowa public drinking water utilities using cell-based assays. Sci Total Environ 714: 136317. [crossref]

61. Cavallin JE, Durhan EJ, Evans N, Jensen KM, Kahl MD, et al. (2014) Integrated assessment of runoff from livestock farming operations: Analytical chemistry, in vitro bioassays, and in vivo fish exposures. Environ Toxicol Chem 33: 1849-1857.

62. Hotchkiss AK, Rider CV, Blystone C, Wilson VS, Hartig PC, et al. (2008) Fifteen years after "Wingspread"--environmental endocrine disrupters and human and wildlife health: where we are today and where we need to go. Toxicol Sci 105: 235-259.

63. Kolpin DW, Furlong ET, Meyer MT, Thurman EM, Zaugg SD, et al. (2002) Pharmaceuticals, hormones, and other organic wastewater contaminants in U.S streams, 1999-2000: a national reconnaissance. Environ Sci Technol 36: 1202-1211. [crossref]

64. Delfosse V, Grimaldi M, Pons JL, Boulahtouf A, Maire AL, et al. (2012) Structural and mechanistic insights into bisphenols action provide guidelines for risk assessment and discovery of bisphenol A substitutes. Proc Natl Acad Sci U S A 109: 14930-14935. [crossref]

65. Goldstein I, Paakinaho V, Baek S, Myong-Hee S, Hager GL (2017) Synergistic gene expression during the acute phase response is characterized by transcription factor assisted loading. Nat Commun 8: 1849.

66. Voss TC, Schiltz RL, Sung MH, Yen PM, Stamatoyannopoulos JA, et al. (2011) Dynamic exchange at regulatory elements during chromatin remodeling underlies assisted loading mechanism. Cell 146: 544-54. [crossref]

\section{Citation:}

